\title{
Exploration and Discussion of Design Education Reform under the Context of Social Transformation
}

\author{
Wang Li \\ Dalian Institute of science and technology, No.999-26,Bingang Road,Lushunjingjikaifa District, \\ Dalian City Liaoning Prov. China
}

258769077@qq.com

Keywords: social transformation; design education; transformation methods

\begin{abstract}
Rapid development of the Internet has brought huge changes to commercial modes, lifestyles and social organizations, and also raised new questions for design practices. Traditional design subjects can hardly meet demands of increasingly extensive application fields, nor can they effectively explain new practical experiences. Under the new social context, service objects and content of design are changing, so connotation of design education, talent development modes and evaluation system should be redefined.
\end{abstract}

\section{Social transformation background of design education}

As the human society evolved from the mechanical manufacturing era to the information electronic era to finally the current Internet era, the scope of traditional design has been expanding, thus involving more complex procedures. Undoubtedly, the social context has been changed, no longer being the one facing traditional design, and different era backgrounds can generate different design education concepts, connotations and talent cultivation modes. Since establishment of Bauhaus University in Germany, design education has been evolving along with social reforms, economic transformations and technological update.

Along with rapid development of Internet technology in recent years, commercial modes, lifestyles and social organizations have undergone drastic changes. Design practices have been faced with new challenges, that is, how the design industry should serve demands of China's economic transformation and social relationship reconstruction in the Internet era and how the design education targeted at bringing up future design talents should be transformed.

On the one hand, due to new integration of design, technology, engineering and commerce, design subjects have taken on a look different from that of traditional ones. On the other hand, during the extensive transformation of commerce and society, technological development has created more possibilities for design. However, lack of professionalism and design research is becoming a bottleneck of social innovation. A reinterpretation of design dimensions, methods and practices can undoubtedly boost development of design subjects and theories, and innovation success of commercial products, services and modes.

In the Internet era, design has become an important part of user experience improvement, strategy formulation or a more complex system. An increasing number of design works have found ways to integrate with technology, engineering and commerce. Gradually, design has become a synonym of commercial innovation or social transformation. Today's design education is restructuring based on issues of different complexity. The design-driven innovative thinking is increasingly involved in commerce and even in the issue of sustainable social transformation.

Design education should attempt to be a reflective practitioner using design tools and procedures to reflect on lifestyles, future products, facilities, environment, health and food to support positive social and environmental changes. Transformational design aims at not only achieving new development of design knowledge, abilities and paradigms, but also arousing reflections on design. The original intention of design is not confined to success of commercial products. Instead, it is 
shouldered with the responsibility of promoting sustainable social development through design, and creating a new world for all mankind.

\section{Problems existing in the traditional design education}

Under the context of the Internet era, traditional design education is faced with the following three problems from the perspective of design subject paradigm reform and economic transformation.

\section{Mutual isolation among various design subjects}

Design subjects for different design majors and even for the same major are isolated from each other. Even if a course has an in-depth and systematic research of certain issue, mutual isolation makes interdisciplinary research and integration impossible.

\section{Deviation from social application areas}

The traditional design subjects cannot meet demands of increasingly extensive application fields, because their teaching content and teaching modes fail to accommodate to the fast-developing social background. Narrowness of application fields - this is a critical problem that design education must resolve.

\section{Lack of diversified talents caused by rigid specialty classification}

Current design issues have become increasingly complex, thus putting forward a higher requirement of talents' comprehensive abilities. The nature of many practical design issues can be hardly defined. It is hard to tell which specialty can cope with them. More often than not, knowledge of multiple specialties should be combined to resolve them.

\section{Exploration and discussion of approaches for design education reform}

Design education should inspire new explorations and research in response to technological, social, economic and industrial changes. In particular, some design colleges should establish proper school running guidelines and clarify talent development goal according to the era development trend and their own characteristics, and realize these goals through the teaching framework and specific courses.

\section{Establishment of a problem-oriented (project-oriented) talent training mode}

To respond to the industrial development and transformation requirements, design colleges should clarify their problem-oriented (project-oriented) talent training mode. In other words, design problems should be integrated into the research process. Only when practices and research are combined can favorable outcomes be achieved. The extensive and shallow knowledge learning should be replaced by the intensified improvement of operational abilities. The narrow shape aesthetics should be replaced by the multi-dimensional product design. The short courses seeking superficial understanding should be replaced by the progressive long-term projects. Social, livelihood, economic and technological problems can also be turned into opportunities for development. Being people-oriented and user-centered, design teams can make use of resources of different design specialties to finish their design projects.

\section{Creation of a compound curriculum system based on a diversified faculty}

The boundaries between colleges and specialties should be blurred so as to enhance interdisciplinary research. Talents of other subjects, such as Sociology, Psychology, Commerce and Management Science should also be introduced to the faculty. Excellent talents from enterprises should be invited to give lectures on a part-time basis. By doing so, design colleges can foster quality faculty resources, which can provide effective support for comprehensive development of design subjects. Besides, specialized courses are enriched by optional courses, thus enabling 
students to think about design and create things from the perspective of "problems", "consciousness", "individuals", "society" and "market". In this way, design thinking, methods and skills can be applied to multiple fields. This can also show the interdisciplinary and open nature of design education.

\section{Development of students' comprehensive abilities through experience learning}

Design education is not just to delivery some information, but also to spread experiences. With these experiences, learners can achieve new creations. Practical experiences allow learners to observe and think about problems from different perspectives. By doing so, learners can come up with logically feasible concepts and theories, and test their feasibility in a new environment. Based on relevant experiences and theories, learners can make decisions and solve problems, and foster students' comprehensive abilities, such as application, innovation, communication and cooperation.

\section{Promotion of mutual integration between subjects and regional characteristics}

Design colleges should combine their own advantages and city characteristics to form their subject characteristics. The curriculum design should be closely combined with the city's geographical, economic and cultural characteristics. If being separated from these carriers, the curriculum design will lose its meaning. How to build the framework of design education based on regional characteristics - this is a basic issue that all design institutions should pay attention.

Besides, effective management systems and measures should be adopted to guarantee smooth implementation of the newly-designed curriculum system and talent development mode. Educational concepts and development modes of a school, no matter how well-designed they are, should be promoted by more human-oriented management systems and measures.

\section{Conclusions}

The vision of design education is to bring up first-class designers and researchers for the future society. Design education should not be confined to creations and knowledge in a specific field. It should accommodate to social transformation and challenges, and provide strategies, systems and services to cope with these challenges.

A qualified designer should be equipped with advanced design concepts and ideas and a strong sense of responsibility and mission. In order to promote the country's industrial transformation and development and increase competitiveness and influence of national brands in the international arena, designer colleges should do a good job in bringing up compound design talents with an international vision, an innovative mind, and good communication, cooperation, design development, transform, coordination and management abilities.

\section{References}

[1] Claus Lehman: Design Education and Education Design (Jiangsu Phoenix Art Publications, China 2016)

[2] (th) Kurokawa Masano: Century Design Proposal (Shanghai People's Fine Arts Publications, China 2003)

[3] Lou Yongqi: new design Activism,for the transformation and design" International Design Education Forum lecture record 2016

[4] Wei Jie: Teaching Reform in the Design Institute of Jiangnan University, Design Education Redesign Report 2016

[5] Lou Yongqi: the active design of the transformation of the times, "decoration" special planning "active design" 2015 
[6] (US) Victor Papanaik: design for the real world, Zhoubo translation, (CITIC Publications, China 2003) 